\title{
MODERN DIDACTIC TERMS IN THE CONTENT OF LATVIAN LANGUAGE AND LITERATURE STUDIES
}

\author{
Anna Vulāne \\ Elita Stikute \\ Latvijas Universitāte
}

\begin{abstract}
The article is devoted to a pending matter in the Latvian linguistics and methodology of language and literature - the formation of the system of terminology.

The 90-ies of the 20th century when Latvia gained its national independence brought changes not only in the political and economic life but also in the terminology because new realities, which appeared in life, needed new names. Essential transformation in education brought along changes in the nomination system of the specific realities in the sphere. By establishing broader contacts with the pedagogical information field of the Western countries, translating scientific articles one comes in touch with specific concepts of the sphere for which there are no matching nominative units in Latvian and, judging by publications, in most cases equivalent terms are successfully formed. Unfortunately, this is not true of all innovatons, which, due to lack of time, amount of work or other reasons, in most cases are not submitted to language experts or the terminology commission for approval. The research provides analysis of several terms used in the methodology of the Latvian language and literature, as well as other subjects, yet are contraversial from the viewpoint of terminology and the quality of the Latvian language.

The research presents the analysis of the semantic structure of active teaching methods and methodological approaches in language and literature in the context of the Latvian language world view with the aim to encourage teachers, lecturers of institutions of higher education, specialists in pedagogy and didactics and other people concerned to consider whether one or another name (which can hardly be referred to as 'term') fits into the education process.
\end{abstract}

Keywords: terminology, methods, Latvian language, literature, methodology

\section{Introduction}

The development of scientific terminology is closely linked with the development of science, therefore formation of terminology is always urgent as long as science itself is progressing (Skujina, 1993:5). A term is an essential part of expressing and perceiving scientific thought, part of acquiring and storing scientific experience, it is like an intermediary between the scientist's thought and society, therefore terms must be precise and clearly convey the concept, thus ensuring united perception and comprehension. Present-day society is interested in the formation of terms in different spheres, on the one hand, due to the growing need for new and precise equivalents for foreign terms, and, on the other hand, people come in touch with the terms of various spheres - at school, institutions of higher education, in their professional work and everyday life. Therefore, the language of science has come into researcers' focus of attention in the last two decades research works both on terminology and the specific chatacter of science language were published, several hundred dictionaries of terms were compiled, among them Explanatory Dictionary of Pedagogical 
Terms (PTSV, 2002), Explanatory Dictionary of Lingvodidactic Terms (LTSV, 2011), Explanatory Dictionary of Basic Terms in Linguistics (VPSV, 2007). At the same time we are confronted with a serious problem - science language as such and the linguistic quality of terms in different spheres and their compliance with the Latvian world perception and the nature of the language. As we know, „the meanings of separate signs are not isolated in the speaker's perception, they form imaginary semantic clusters together with other meanings" (Caré, 1999:39). Already in 2003 D. Nîtina paid attention to the problem which appears to be current also ten years later. „Whether we like it or not, we must admit that it is the scientific texts where the Latvian language quality is getting worse, though it should be vice versa - scientific texts should be samples of good language" (Nìtina, 2003:373). In the recent researches of terminology attention has been paid not only to the formation of terms, their meaning and compliance with the terminology system of the sphere but also to their communicative and stylistic function (Caré, 2003) because in many spheres the term functions not only in the speech of specialists but also other members of society.

The 90-ies of the 20th century when Latvia gained its national independence brought changes not only in the political and economic life but also in the terminology of many spheres because new realities, which appeared in life, needed new names. Essential transformation in education brought along changes in the nomination system of the specific realities in the sphere. Many specialists have an opportunity to familiarize themselves with the experience of the Western countries in conferences, seminars, projects, scientific publications, by joining TEMPUS programme, courses organized by Soros Fund Latvia and so on. By establishing broader contacts with the pedagogical field of the Western countries, translating scientific articles one comes in touch with specific concepts of the sphere for which there are no matching nominative units in Latvian and, judging by publications, in most cases equivalent terms are successfully formed. Unfortunately, this is not true of all innovations which, due to lack of time, amount of work or other reasons, in most cases are not submitted to language experts or the terminology commission for approval.

"Under the existing circumstances there is often not sufficient time in the process for consultations and a deeper insight into the problem, besides at first it is impossible to foresee whether the relevant concept will have a long or short life, whether it will be widely used also outside one specific sphere or have only an episodic and temporary usage in a narrow and specialized context." (Baltiņš, 2007:32). As a result, words of random choice or loan translations (calques) appear, the semantic structure of already functioning Latvian word or an earlier loan is unnecessarily expanded, a lexeme that does not fit into the nomination system of the Latvian language and does not comply with the requirements for the term is chosen because 'under the influence of the English language terminology changes (another intermediary language with a certain pressure of its structure), direct loans enter the Latvian language, part of the old terms are 
replaced by new ones. Free migration of terminology characteristic to the language of primary terminology takes place from sphere to sphere (Veisbergs, 2003:26).

\section{Research Methods}

In order to implement the set aim - to researech the terms formed at the turn of the 20th and 21st centuries and used to name the methods and methodological approaches applied in language and literature, their semantic compliance with the essence of the concept and appropriateness to the Latvian language world view the following methods were used:

- theoretical sources - scientific publications on the approach of critical thinking, cooperative studies and interactive methods - linguistic analysis,

- analysis of the semantic word structure,

- descriptive method, as well as

- analysis of the authors' work experience.

\section{Theoretical background and results}

A term is a language sign that refers to a specific professional sphere. As pointed out by K. Averbuhs and V. Skujina, a term is a functional unit, a word in a special function as a lexical unit acquires the status of terminology through its sphere of usage and functional meaning (Skujina, 1993:7). The task of a scientific term is to express, in other words, nominate and mark, i.e., by using minimal means of language to define the concept of a relative sphere as precisely as possible, at the same time pointing to the place of the concept in the system of concepts of the relative sphere. (Skujinna, 1993:8) The usage sphere of the term is viewed in a narrower and broader meaning. In a narrower meaning science language is recognized as the usage sphere of the term and the term is a word that has a definite place in the concept system of some branch of science which determines the functional meaning of each term. (For more details see Skujina, 1993:7). A word or word combination may function as a term (terminological combination of words) that conveys a definite concept of science, technique, art or other special branch which must be distinguished from other concepts. Therefore, when terminolizing lexemes it is necessary to choose a structure of the term that contains the most essential features, the ones that are necessary and sufficient.

According to ISO 704 requirements the term must possess transparency, regularity, adequacy, linguistic economy and derivative properties. Accuracy of the language is another essential feature which means that the neologism or loan term is adjusted to the system of the relative language and complies with its standards. No less important is the indication that native words are preferable in the formation of terms. In addition, when forming a term one must consider also the appropriateness of the new word to the world view of the language of the 
relative ethnos, among them the system of metaphores, because many terms are based on metaphores. The term, in the same way as any meaningful word, links the language and reality and reflects the objects of the real world.

In the study process we regularly come into contact with various didactic and pedagogical terms both successful creations, fully complying with the Latvian language system and basic principles of forming terms and those that are puzzling, unintelligible, can be misunderstood or cause objection. Unfortunately, there is rather a great chaos in the terminological system of the language and literature didactics as it is unclear what is meant by a teaching method and a methodological approach and which of the array belongs to methods, which to the body of methodological approaches and so on. It seems, the nomination process of methods and methodological approaches is left unaided and everyone does as they please. Such a disorder in the branch causes far-reaching consequences both in the content of education documents (Programma, 2005; Programma, 2006; LVLMIP, 2005) and teaching aids. Lexemes inappropriate for the Latvian language, claiming the status of a term appear in the speech of teachers, professors of institutions of higher education. All this creates an impression in the pupils and students that names like akvārijs (aquarium), čuska (snake), spogulis (mirror), stūri (corners), balsošana ar kājām (voting with feet), lasǐšanas stratēgijas (reading strategies) and so on is anormal phenomenon in terminology of Latvian (in contrast with English). However, we will not find in the Explanatory Dictionary of Lingvodidactic Terms (VPSV, 2011) any of the names of those peculiar methods and methodological approaches (which part of specialists call strategies, like in the English language) analysed in the research. Inadequate use of words in the study process create a strange reaction - pupils may conclude that part of the lexemes have only the status of a sign - they are used to name something that does not comply with the essence of the concept. Unfortunately, due to the linguistic indifference of a great part of society, among them well-educated specialists, shortage of terminology specialists and other reasons such functionally illogical signs and calque texts are on the increase in the Latvian language of science. It is therefore even more important to use proper terms in the educaion process of the young generation and to shape their understanding of the specifics of forming terms.

Before the linguistic analysis of separate newly-introduced teaching methods and metodological approaches we would like to point out that at times, trying to unify and disregarding the fact that language serves not only as a means of communication but also as a means of world cognition, accumulation and transference of ethnic and individual cultural experience, we can lose essential cultural information and convwy misleading ideas. When reading Education Law of the Republic of Latvia (LRIL, 1998) we are faced with unpleasant surprise - culture-rich words - skola (school), skolēns (pupil) and skolotājs (teacher) have been removed from it and replaced by izglìtības iestāde (educational institution), izglïtojamais (learner) and izglītotājs (educator) - 
more convenientin use. If we want to retain the ethnolinguistic information contained in the language, functional convenience should not become the decisive criterion in the choice of terms. Of course, the above designations may refer to any person who studies, any institution where studies take place and anyone who teaches. However, the lexeme school and teacher is a cultural sign, moreover, a world-scale cultural sign. It is a pity that for mercantile reasons it has been removed from normative documents. The words learner, educational institution, to a certain extent, also educator are neutral verbal signs that do not contain cultural value accumulated in Latvian over centuries and axiological information. There is a difference whether we say māte (mother) or sieviešu dzimuma bütne, kura laidusi pasaule bèrnu (a being of feminine gender who gave birth to a child). How should pupils write now? 1. klases izglìtojamā Ulda Ozola pieraksti? 2. kursa izglītojamās bakalaura darbs? (Notes of the 1st grade learner Uldis Ozols? Bacholer degree paper of the 2nd year learner?) And what to do with Teachers' Day (Skolotajju diena)? Must it become Educators' Day (pedagogu diena)? The line of questions could go on, because by changing something at one functional level we must keep in mind what happens at others and make sure whether the gain is greater than the loss. Disregard for the Latvian language rules and semantic nuances has developed a situation where the newly-formed term learner (izglìtojamais) in its very essence does not comply with modern and postulated necessity to shift from the teacher-centred study process to the pupil-centred, humane education process because the form of the declinable passive participle of the verb educate is a synonym of the debitive mood form and means 'one who needs to be educated'. We will not find the semantic element 'education, cooperation' in the semantic structure of the substantivized word; it only contains the action directed towards the object and besides has the mandatory element to it - one who needs to be educated. (Vulāne, 2011). Unfortunately, in the sphere where the word should be treated with respect we notice that the meaning of familiar and semantically stable lexemes in the Latvian language is expanded, amorphous verbal signs appear, spread like a virus and are as hard to fight as flu in all its metamophoses.

Thus, in the 90-ies a term of the literary theory in the Latvian language eseja (English essay $<$ French essai 'trial, test') - a short piece of writing on some scientific, philosophic, and especially literary or art problem' - the semantic structure (according to the English language) was supplemented with the meaning of 'composition written by a pupil(student) at the end of a course or theme as a special test which may have research elements' (PTSV, 2000:51), ignoring the fact that the Latvian language has terms more precisely naming the written work now called an essay - a composition, a survey etc. In Canada, the USA and England a lot of time is alloted to developing the skill of essay writing, study courses are provided in institutions of higher education, while in Latvian schools essay writing is practised in various subjects already in primary school, before pupils have even the slightest idea of what an essay is. Furthermore, the 
number of Latvian language and literature classes has drastically been reduced, and, for that reason, the time alloted to practising the skill of essay writing is hardly sufficient. So, a term used mostly without proper content, degrading its sense and misleading the public, has been introduced. The same can be said about words mācìbu darbìba (action of studying) (and other actions, undertakings, meetings, seminars etc.) which, for some reason, has been renamed aktivitāte (activity) (Burkevica et al. 1999:90) but mācību pañēmieni (teaching approaches) are called stratégijas (strategies or means) (Burkevica et al., 1999). Though the concept strategy has been precisely defined in the Explanatory Dictionary of Pedagogical Terms (PTSV, 2000:166) also in the context of pedagogy, still the inadequate designation reading, listening, learning etc. strategies appear in the Latvian language standards, model programmes and teaching aids.

A second problem arises from mixing the phenomena of different spheres and levels. Do we call a composition, an essay, a review, a table etc. methods or methodological approaches? Though such notions have not been expressed in the research of linguistic and didactic experts (Laiveniece, 2000; Laiveniece 2003; Anspoka, 2008, Stikute, 2011), still one or another genre of speech, type of summarizing information etc. has been mentioned both in the Latvian language model programmes, as well as in the wide range of teaching aids, teaching methods and methodological approaches.

The third problem, as pointed out before, refers to the names of teaching aids and methodological approaches. Side by side with successfully formed (or translated) lexemes there are odd language units that claim the status of the term, yet do not comply with good terminologization practice, e.g., akadēmiskie pretstati (the academic contrasts), dzīvais dzejolis (live poem), četru rūšsu logi (four-pane Windows), gerbonis (coat of arms), pārdomu logs (the window of reflection), punktētā diskusija (the dotted discussion), pildspalva vidū (fountain pen in the middle), sajauktā secība (mixed sequence), zigzags (jigsaw), aktīvās piezīmes (active notes), akvārijs (aquarium), zini, gribi zināt, mācies (know, want to know, learn) etc. (Golubova \& Ikale 2009; Rune, 2003; Rubana, 2000; LVLMIP, 2005; Plaude, 2004 etc.) When evaluating these lexemes from the viewpoint of the requirements set for terms, confomity can hardly be found. It seems, this time the metaphore would not be the greatest fault because metaphorization has reached global character (Sīlis, 2009:106).

All in all, the principle of conceptual clarity and term transparancy has not been observed because without a definition and a more detailed explanation these terms cannot be understood and linked with a definite meaningful system. Other principles (see the aforesaid) have not been respected either.In addition, in the so-called descriptions (Golubova \& Ikale, 2009; LVLMIP, 2005) of teacing methods or methodological approaches (the authors' opinions differ) the term is not defined at all, except providing the information what can be achieved with the methodological approaches and how to use it. 
Let us analyse some lexemes.

The Academic Contrasts. The method develops pupils' critical thinking, the ability to argue and defend one's own point of view, to agree on a common position.

The teacher puts forward a theme/problem with two possible opposite statements or solutions. Pupils work in groups of four. The groups split in two pairs, each pair is told which position they have to take and defend. The pairs are given a definite time to think over their arguments that substantiate their position. Then the pair separate for a while, each pupil joins a pupil with the same position from another group, they discuss the set arguments and add them to their lists. Then the pupils return to their initial partners and put down the elaborate substantiation of their position: "We consider that ..., because ..." Each pair expresses their arguments to the pair of the other group and defends their point of view. The participants of the other pair listen and put down. In the end the groups work out a united position which they substantiate by using the strongest arguments expressed in the discussion. (LVLMIP, 2005:124-125)

As seen from the description, the debating principle is at the basis with some variations introduced. The semantics of the components in the analytical lexeme are only distantly linked with the intended meaning as not one of the semes in the first component can be connected with what happens at the relative stage of the study process. Lexicographical sources indicate that the word academic (akademisks) is something that 1) refers to academy, 2) is tested in research, complete, 3) refers to institutions of higher education, 4) is purely theoretical, abstract, has no practical meaning, 5) strictly observes canons, 6) is reserved and dry (Baldunčiks, 1999:31). Pupils have to express an oppsite point of view and substantuate their thoughts, which can be considered as a contrast. If the dominant component of the analytical lexeme cannot be semantically linked with the second, such a combination of words falls apart and cannot be used. Besides, a special name is hardly necessary for the type of debates as the directions include an explaination of the procedure.

The same can be said about the names of formal variants of the discussion akvārijs, punktētā diskusija, koncentriskie apļi (aquarium, the dotted discussion, the concentric circles). The names show in what position the active and less active participants are arranged, namely, if those delegated by work groups to express their opinion gather in the centre of the room, it is called aquarium; if the active debators sit in the centre, in a circle, but the observers and the assessors are outside, the dotted discussion takes place; if the participants of the outer or inner circle change places and roles after some time, the disussion is called the concentric circles. As we see, the name of each discussion variant has been formed based on different principles and using dissimilar associations and as such they turn into real puzzles instead of being self-explanatory. 
The teaching aids of language, especially literature often contain a task where pupils are encouraged to compose a live poem (dzivvais dzejolis) by making it as an answer to the given questions on a certain text or theme.

1 Name, surname

2 What four features characterize it?

3 Whose? (sister, brother, wife, husband and friend etc.)

4 Who loves (what? whom?) (three objects(?!) or people)

5 Who, what feels (how?) (three objects or people)

\section{A Live Poem}

6 Who needs (what, whom?) (three objects or people)

7 Who is afraid of (what, whom?) (three objects or people)

8 Who devotes himself/herself to (what, whom?) (three objects or people)

9 Who would like to see (what, whom?)

(three objects or people)

10 Who lives (where?)

In this case, too, the name is confusing because what the pupil has created is not a poem, to say nothing about it being dead or alive. Names of such type are a contrast to the nature of things and should not be used in education process.

Term-creating principles have not been observed when forming the names of teaching approaches for characterizing a pupil or a character, namely, coat of arms (its shape, the idea of shaping its visual image is used for structure-based information), four-pane windows, four-window microscope, the window of reflection, (the necessary information is entered into a four-part table). The above names specify only the form in which a thought, an assessment of an object, or a visual image is reflected, but they do not convey the essence of the methodological approach. In addition, they are semantically incorrect, confusing and polysemantic notions.

One type of group work has acquired the status of a methodological approach (elsewhere - that of a method) and the name of jigsaw (zigzags) though its association with the name is relative, besides, it is already being used in sewing technique zigzagdūriens (a zigzag stitch) and everyday speech to designate a series of alternate sharp trurns in opposite directions (a broken line). It is also an example of how the individual has been separated from the whole and generalized. Group work is one of the forms of education, it can be modified conveying the essence of each modification in the directions, therefore it is hardly necessary to call it a methodological approach as other modifications of group work do not have a separate name.

The descriptive designations of everyday talk such as pildspalva vid $\bar{u}$, sajauktā secība, aktīvās piezīmes; zini, gribi zināt, mācies; svarīgākais teikums; Atrodi savējos!, Atstāj pēdējo vārdu man! Saki kaut ko! (fountain pen in the middle; mixed sequence; active notes; know, want to know,learn; the best sentence; Find your own people!, Leave me the last word!) etc. do not fit into the system of terms at all, they sooner match the models nominating games and plays, than term formation. The names of methodological approaches, like Coaching, Cort, 
$P O, P M I$ and others also deserve criticism. Dictionary, letter, description, chart, table, file and different other speech genres, text types or ways of summarizing information fall neither under the category of a method nor a methodological approach.

More and more loan words for methods and methodological approaches that do not comply with the specifics of a definite school subject appear in methodology, e.g., Spider and Snake. Literature as a subject of art has to activate pupils' ethic and aesthetic values, provide positive and emotional background for studies. How does the methodological approach Spider (zirneklis) and Snake (čuska) relate to the essence of literature as a subject of art? It is generally known that many pupils are frightened of spiders and snakes which arouse dislike. How is a pupil supposed to work with a Spider and a Snake then? How pedagogical and ethic is it to offer pupils such methodological approaches as Proppa cards, bingo that come from gambling vocabulary, crossword puzzle with a crib, as well as the crib system in different subjects propagated by the publishing house Zvaigzne $\mathrm{ABC}$ - remains an open-ended question.

The much-popularized name of methodology by E. de Bono „Six Thinking Caps" and its compliance with the system of Latvian grammar also gives food for thought. In order to enhance the efficiency of thinking E. de Bono created the method of six thinking caps, its explanation is as follows: by putting one of the caps on the head a certain type of thinking is activated. The author uses the cap as a thinking metaphore as in the culture there exists a deeply-rooted association: thinking-head-cap. The cap illustrates the role we have chosen at the moment. The cap can be easily put on, taken off and it is noticed by everyone. The same can be said about man's way of thinking. When putting on a cap, colour or style is emphasized; choosing the way of thinking, the stress is on the process and goal. Unfortunately, in the Latvian world perception and manner of speaking the cap does not play the role described above (see site www.radosumapils.lv). This statement is at variance with the Latvian world perception where the cap has no such function.

Unfortunately, there is neither didactics nor pedagogical subcommission in the Terminology Commission of LAS (see site http://termini.lza.lv) which means there is no one to handle the major problems in the terminology sphere of these branches. However, it is an issue that should not be left without due attention as the word is not only a sign, it is also a means of influence while the term is an essential component of our scientific world view. A disorderly terminology of the branch causes problems in the professional work of teachers and university lecturers, the discrepancy between what the teacher of Latvian tells his/her pupils about the specific features of a scientific language, the formation of a scientific text and the so-called terms they use daily in the study process.

We would like to request experts of didactics in cooperation with linguists to servey the specific vocabulary of the branch, to define more precisely what is 
meant by a teaching method and a methodological approach, as well as to determine and systematize the array of the methods and the approaches.

\section{Conclusions}

All in all, the authors of teaching and methodological aids, education documents, and course lecturers have tried to name more precisely various actions, teaching forms and types so as to provide the so-called key words and the teachers would not waste time in class on detailed explanations what pupils have to do. The wish is certainly worthy of respect, yet not all the designations formed in the last two decades claiming the status of branch terms are always acceptable.

It is high time the subcommission of pedagogical and didactic terminology was established in LAS and a proper branch terminology was developed. Needless to say, that anyone, who comes in touch with a rather disorderly didactic terminology, should treat the WORD with concern, critically accepting a suitable and successful term while avoiding inserts of academic contrasts and zigzags in dialogues with learners in the context of media pedagogy.

We would like to believe that industry professionals, among them lawyers, civil servants of ministries who work on all sorts of education documents, regulations of projects, write doctoral theses and create other texts will think in Latvian, listen to the opinion of linguists (see Baldunčiks, 2005; 2006; 2008; Baltiņš, 2007; Skujiña, 1993; Nìtina, 2003, Laugale, 2002 etc.) and not pollute the language with literal, superfluous loans from English and other languages, keeping in mind that proficiency of a foreign language is an asset, but in the Latvian research and pedagogical space perfect knowledge and skill of the native language is of a higher value.

Work on new terms demands a profound understanding and structure-based knowledge about the system of terms in the branch, their semantic and functional specifics, models of formation therefore success can be achieved only in cooperation with competent terminology experts and industry professionals.

\section{References}

1. Anspoka, Z. (2008). Latviešu valodas didaktika. 1.-4. klase. Rīga: RaKa.

2. Baldunčiks, J. (2008). Terminologiskie mutanti mūsdienu latviešu valodā. In G.Smiltniece (Ed.), Valodas prakse: vērojumi un ieteikumi, 3 (pp. 26-37). Rīga: LU.

3. Baldunčiks, J. (2006). Anglu-latviešu tulkotāja viltusdraugi: teorija un prakse. In I. Žogla (Ed.), LU raksti, 700. Pedagoǵija un skolotāju izglītība (pp. 260-269). Rīga: LU.

4. Baldunčiks, J. (2005). Neparasts daudzskaitlis mūsdienu zinātnes un izglītības valodā. In A. Veisbergs (Ed.), Latviešu valoda - robežu paplašināšana (pp. 6-12). Rīga: VVK.

5. Baldunčiks, J. (Ed.) (1999). Svešvārdu vārdnīca. Rīga: Jumava.

6. Baltinšs, M. (2007). Terminoloǵijas procesa normatīvā bāze: esošais un vēlamais. In A. Veisbergs (Ed.), Latviešu valoda - pastāvīgā un main̄̄gā (pp. 32-53). Rīga: VVK.

7. Burkevica, O. et al. (1999). Metodikas rokasgrāmata skolotājiem. Rīga: LVAVP. 
8. Cabré, M. T. (2003). Theories of Terminology: their description, prescription and explanation. Terminology, Vol. 9, Nr. 2, 163-199. Retrieved December 5, 2013 from http://www.hf.uib.no/ forskerskole/cabre.pdf

9. Cabré, M. T. (1999). Terminology: Theory, Methods and Applications. Amsterdam, Philadelphia: John Benjamins Publishing Company. Retrieved December 5, 2013, from http:/www.worldcat.org/title/terminology-theory-methods-and-applications/oclc/ 70769318/viewport

10. Golubova, V., \& Ikale, I. (2009). Ideju banka 1. Mācību metodes un metodiskie pañēmieni. Rīga: Zvaigzne ABC.

11. ISO 704:2000/TC37/SC1. Terminology work. - Principles and methods. Retrieved September 17, 2013 from http://www.ap233.org/ap233-public-information/reference/ ISO-FDIS-704-Terminology-Development.pdf

12. Kas ir sešas domāšanas cepures? Retrieved December 2, 2013 from ttp://www. radosumapils.lv/index.php? $\mathrm{p}=9476 \&$ kategorija $=\mathrm{Par} \% 20 \mathrm{rado} \% \mathrm{EF} \% \mathrm{BF} \% \mathrm{BDo} \% 20 \mathrm{dom} \%$ EF\%BF\%BDanu\%20Latvijas\%20skol\%EF\%BF\%BDs\&page=2\&b=1\&lbu=9362\&lang=

13. Plaude, I. (Ed.) (2004). Kooperatīvā mācīšanās. Rīga: RaKa, 2004.

14. Laiveniece, D. (2000). Valodas didaktikas metodiskie jautājumi. Rīga: RaKa.

15. Laiveniece, D. (2003). Valodas mācības pusaudzim. Rīga: Raka.

16. LRIL - Latvijas Republikas Izglītības likums, 1998. Retrieved January 20 from http://izm.izm.gov.lv/normativie-akti/likumi/912.html

17. Laugale, V. Citvalodu ietekme pedagogijas terminoloǵijas veidošanā. In B. Laumane (Ed.), Vārds un tā pētišanas aspekti, 6 (pp. 240-245). Liepāja: LiePA, 2002.

18. LTSV - Skujiņa, V., Anspoka, Z., Kalnbērziņa, V. \& Šalme, A. (2011). Lingvodidaktikas terminu skaidrojošā vārdnīca. Rīga: Latviešu valodas aǵentūra.

19. LVLMIP - Latviešu valoda un literatūra 1.-9. klasei skolām, kas īsteno mazākumtautību izglītības programmas. Mācību priekšmeta programmas paraugs. Rīga: ISEC, 2005. Retrieved November 28, 2013 from http://visc.gov.lv

20. Nītiņa, D. (2003). Daži profesionālās valodas pragmatiskas aspekti. In B. Laumane (Ed.) Vārds un tā pētǐšanas aspekti, 7 (pp. 371-376). Liepāja: LiePA.

21. Noteikumi par valsts standartu pamatizglītībā un pamatizglītības mācību priekšmetu standartiem. 2006. gada 19. decembra Ministru kabineta noteikumi Nr. 1027, 13. piel. Latvijas Vēstnesis, Nr. 204 (3572), 2006, 22. decembris.

22. Noteikumi par valsts vispārējās vidējās izglìtības standartu un vispārējās izglītības mācību priekšmetu standartiem. 2008. gada 2. septembra Ministru kabineta noteikumi Nr. 715, 23. piel. Latvijas Véstnesis, Nr. 145 (3929), 2008, 18. septembris.

23. Programma 2005 - Latviešu valoda 1.-9. klasei. Programmas paraugs. 2. variants. Rīga: ISEC, 2005. Retrieved 12 October, 2013 from http://visc.gov.lv

24. Programma 2008 - Latviešu valoda. Programmas paraugs. 2. variants. Rīga: ISEC, 2008. Retrieved 12 October, 2013 from http://visc.gov.lv

25. PTSV - Belickis, I., Blūma, D., Koķe, T., Markus, D., Skujiṇa, V. \& Šalme, A. (2000). Pedagogijas terminu skaidrojošā vārdnīca. Rīga: Zvaigzne ABC.

26. Pudule, I. (2009). Kāda ir jūsu uzņēmuma mārketinga komunikāciju atdeve? Retrieved 12 October, 2013 from http://www.tns.lv/newsletters/2009/23/

27. Rubana, I. M. (2000). Mācīties darot. Rīga: RaKa.

28. Rune, M. (2003). Stratēgijas literatūras apguvē pamatskolā. Rīga: RaKa.

29. Skujiņa, V. (1993). Latviešu terminologijas izstrādes principi. Rīga: Zinātne.

30. Skujiņa, V. (2004). Lai taptu vārds. Valodas ceļi, krustceļi. Rīga: Garā pupa, 5-24.

31. Stikute, E. (2011). Latviešu literatūras didaktika. Rīga: RaKa.

32. VPSV - Bušs, O. et al. (2007). Valodniecības pamatterminu skaidrojošā vārdnīca. Rīga: VVA, LU LVI. 
Proceeding of the International Scientifical Conference May $23^{\text {th }}-24^{\text {th }}, 2014$ Volume I

33. Veisbergs, A. (2003). Zinātniskais stils dažādās kultūrās, to ietekme uz latviešu stilu. In Konferences ,Zinātnes valoda” materiāli. Rīga: Valsts valodas komisija, 22-27.

34. Vulāne, A. (2011). Kādus terminus izmantojam izglītības sistēmā: problēmas pieteikums. In Ar mūsdienu acìm uz klasiskām lietām: saturs un metodika. Rīga: LVA, 7-17.

$\begin{array}{ll}\begin{array}{l}\text { Dr. philol. } \\ \text { Anna Vulāne }\end{array} & \begin{array}{l}\text { Latvijas Universitāte } \\ \text { RPIVA Bērna valodas pētijumu centrs } \\ \text { e-pasts: annav@lanet.lv }\end{array} \\ \begin{array}{l}\text { Dr. paed. } \\ \text { Elita Stikute }\end{array} & \begin{array}{l}\text { Latvijas Universitāte } \\ \text { e-pasts: elita.stikute@lu.lv }\end{array}\end{array}$

